\title{
The role of myeloid-derived suppressor cells in the relationship between chronic obstructive pulmonary disease and lung cancer
}

\author{
Sergio Scrimini ${ }^{1-4}$, Jaume Pons ${ }^{3-5}$ and Jaume Sauled $a^{1,3,4 *}$ \\ ${ }^{1}$ Servicio de Neumología, Hospital Universitari Son Espases, Palma de Mallorca, Spain \\ ${ }^{2}$ Servicio de Neumología, Hospital Regional Dr. Ramón Carrillo, Santiago del Estero, Argentina \\ ${ }^{3}$ Instituto de Investigación Sanitaria de Palma, (IdISPa), Palma de Mallorca, Spain \\ ${ }^{4}$ Centro de investigación biomédica en red de enfermedades respiratorias (CIBERES), Palma de Mallorca, Spain \\ ${ }^{5}$ Servicio de Inmunología, Hospital Universitari Son Espases, Palma de Mallorca, Spain
}

\begin{abstract}
Chronic obstructive pulmonary disease (COPD) is characterized by chronic pulmonary and systemic inflammation. There is strong evidence showing that COPD is an independent risk factor for lung cancer (LC). Chronic inflammatory response can affect all stages of tumour development, from tumour initiation to metastasis. Inflammation also alters tumour immune surveillance. Myeloid-derived suppressor cells (MDSC) are a heterogeneous mixture of immature granulocytic and monocytic cells characterized by an ability to suppress the antitumour activity of T-cells by down-regulation of the T-cell receptor chain (TCR $\zeta$ ) through the catabolism of 1-arginine. COPD and lung cancer share a common pattern of expansion of MDSC associated with TCR $\zeta$ downregulation and T-cell dysfunction. MDSC may impair tumour immunosurveillance in COPD and can potentially facilitate tumour initiation and growth, contributing to explain the increased incidence of lung cancer reported in these patients.
\end{abstract}

\section{Introduction}

Chronic obstructive pulmonary disease (COPD) is an inflammatory lung disease characterized by airflow obstruction associated with destruction of lung parenchyma caused by chronic inhalation of gases and noxious particles, primarily tobacco smoke. Comorbidities and exacerbations contribute to the severity of the disease [1].

COPD is highly prevalent and affects approximately $10 \%$ of adults worldwide [2]. It is the third most common cause of death in the United States, and it is estimated that it will be the third leading cause of death and disability worldwide by 2020 [3].

Comorbidities associated with COPD crucially influence the clinical symptoms, progress and prognosis of the disease [1]. Lung cancer is one of the most significant and common causes of death in COPD patients. Although the underlying mechanisms are not fully understood, lung cancer and COPD are clearly associated, possibly due to chronic inflammation [4-6].

Rudolf Virchow first suggested the potential link between inflammation and cancer in the $19^{\text {th }}$ century. During the last decades there has been clear evidence that chronic inflammation plays a key role at every stage of tumourigenesis, from tumour initiation to tumour progression and metastatic dissemination [7]. Inflammatory cells produce a variety of molecules that can cause DNA mutations, genomic instability, malignant cell proliferation, neovascularization, invasion and metastasis. Chronic inflammation may also favour cancer development by disarming the capacity of the immune system to detect and destroy premalignant and malignant cells, a property known as tumour immune surveillance [7-9].

Myeoid-derived suppressor cells (MDSC) are multi-potent progenitor cells defined by their myeloid origin and their remarkable ability to suppress T-cell responses. MDSC were initially reported to be expanded in cancer patients as a mechanism of immune escape used by the tumour cells [10]. However, the alteration of the myelopoiesis resulting in the expansion and activation of MDSC is also associated with infectious, autoimmune and inflammatory conditions [11].

Our research group and others have described circulating MDSC upregulation associated with T-cell dysfunction in COPD patients $[12,13]$. Moreover, our group has recently shown that the pattern of expansion and activation of circulating MDSC associated with T-cell hyporesponsiveness is similar in COPD and lung cancer patients [14]. These findings suggest that the tumour immune surveillance may be altered in COPD patients without lung cancer. In this review, we discuss the potential role of MDSC as a link between inflammation and cancer in COPD.

Correspondence to: Dr. Jaume Sauleda, M.D., PhD, Hospital Universitari Son Espases, C/Valldemossa 79, Planta 0, Mod. C, 07010, Palma de Mallorca, España, Spain, Tel: 871206718, Fax: 871-90.97.24, E-mail: jaume.sauleda@ssib.es

Key words: chronic inflammation, immunosuppression, Arginase 1

Received: May 31, 2016; Accepted: June 20, 2016; Published: June 23, 2016 


\section{COPD and lung cancer are associated diseases}

Lung cancer is the major cause of cancer-related death worldwide with a poor five-year survival rate of only $16 \%[15,16]$. The number of lung cancer deaths is expected to rise to ten million per year by 2030 [17].

Evidence based on population studies during the middle decades of the $20^{\text {th }}$ century converged to establish cigarette smoking as the leading cause of lung cancer [18]. But, it was later in the 1980s when some researchers focused on the association between COPD and lung cancer beyond a common etiology $[19,20]$. Cross sectional and longitudinal studies confirmed that COPD is a risk factor for lung cancer development independent of smoking history [19-24]. A metaanalysis of prospective, population studies that included 204,990 participants found that 6,185 developed or died from lung cancer in a follow-up period of 9-18 years. Participants with poorer lung function had a greater risk of developing lung cancer, but patients with less compromised lung function (FEV1 $80 \%-100 \%$ predicted) also had a high risk of presenting LC [25]. In a smaller, non-population study, the incidence of lung cancer was greater in patients with mild-to-moderate obstruction in baseline lung function tests [26]. The independent relationship between air obstruction and pulmonary emphysema (the two pathological components of COPD), and the risk of lung cancer was also explored. Results showed that even in the absence of airway obstruction, patients with emphysema had a substantially higher risk of lung cancer $[27,28]$. Taken together, this evidence suggests that there may be mechanistic links between the two diseases.

\section{Myeloid-derived suppressor cells: Linking chronic inflammation and immunosuppression}

\section{Chronic inflammation and immunosuppression}

Chronic inflammation is a common denominator in a variety of conditions that differ in aetiology, such us inflammatory, autoimmune diseases, infections and cancer [29,30]. While chronic inflammation proceeds, normal immune homeostasis becomes affected leading to an immunosuppressive environment [29]. Indeed, in recent years, a variety of studies confirmed a suppression of natural killer (NK) cells and $\mathrm{T}$ cells in several disorders characterized by chronic inflammation via induction of MDSC. Initially, this phenomenon was shown in hosts with tumours as one of the mechanisms to escape antitumour immunity orchestrated by tumours [10]. However, these findings were later shown in different chronic inflammatory non-malignant conditions [11,31].

\section{Myeloid-derived suppressor cells}

In a chronic inflammatory environment, several survival, maturation and blocking cytokines as well as growth factors, such as GM-CSF, G-CSF, M-CSF, SCF, INF- $\gamma$, IL-1 $\beta$, VEGF and IL-3, are released by inflammatory cells and inflamed tissues affecting myelopoiesis by increasing the proliferation of myeloid precursors from immature myeloid cells (IMC) and partially blocking their differentiation. This perturbation of the myelopoiesis results in the generation of MDSC, a heterogeneous population of immature myeloid cells with a remarkable ability to inhibit both innate and adaptive immune response, including NK cells, dendritic cells, macrophages and $\mathrm{T}$ cells [31]. Signal transducer and activator of transcription 3 (STAT3) is regarded as the main transcription factor that regulates the expansion of MDSC [31]. MDSC can be subdivided into granulocytic/ neutrophilic MDSC (G-MDSC) and monocytic MDSC (M-MDSC) and human MDSC have been described to commonly express the myeloid markers CD11b and CD33 as well as CD66b/CD15 for G-MDSC and CD14 for M-MDSC [31,32]. MDSC exert their immune suppressor function through a variety of mechanisms and molecules, including arginase 1 (ARG 1) [31,32]. ARG 1 converts L-arginine (L-Arg) into urea and L-ornithine. Human MDSC release ARG 1 and deprive L-Arg and, thereby, inhibit $\mathrm{T}$-cell function [33-35]. The shortage of L-arginine inhibits $\mathrm{T}$-cell proliferation by decreasing $\mathrm{T}$-cell receptor $\zeta$ expression (TCR $\zeta)$ [36].

TCR $\zeta$ is a critical sub-unit of the antigen recognition complex receptor on the $\mathrm{T}$ cell membrane (TCR) that plays a key role in the process of intracellular signal transduction [37]. Reduced TCR $\zeta$ expression affects the normal functioning of the $\mathrm{T}$ cell by impairing signal transduction between the TCR and transcription and gene expression factors which cause lower lymphocyte proliferation and reduced production of effector molecules [30,37]. Similar to MDSC, various chronic inflammatory conditions, including cancer, chronic infections (e.g., HIV, active tuberculosis, leprosy), and autoimmune diseases (e.g., systemic lupus erythematous and rheumatoid arthritis), are characterized by a reduction in TCR $\zeta$ expression, associated with defective $\mathrm{T}$ cell function [30]. Both in vitro and in vivo studies have demonstrated that MDSC modulate $T$ cell function by reducing the TCR $\zeta$ expression [38-41]. This observation has led to the interpretation that both are protective mechanisms orchestrated by the host for lessening potential tissue damage from a persistently stimulated immune system at the price of immunosuppression [30,31].

\section{Myeloid-derived suppressor cells in COPD and lung cancer}

COPD is characterized by an enhanced inflammatory response of the lungs to inhaled particles and gases, particularly cigarette smoke [1], associated with increased circulating levels of inflammatory biomarkers, cytokines, acute phase proteins, and inflammatory cells, indicating the presence of additional systemic inflammation [42-45]. Recent studies highlight an emerging and complex role for MDSC in chronic inflammatory pulmonary diseases of different aetiologies, including lung cancer, asthma, cystic fibrosis and tuberculosis [4648]. Our group and others have shown that MDSC are involved in the immunopathogenesis of COPD [12,48]. Our study provides evidence that expansion of circulating MDSC in COPD patients is associated with increased serum levels of ARG 1 and TCR $\zeta$ downregulation [12]. Other researchers reported similar findings: MDSC expansion was associated with increased levels of functional suppressor regulatory $\mathrm{T}$ cells (T-reg) and exhausted $\mathrm{T}$ effector cells (programmed death 1 $\left.\left[\mathrm{PD}-1^{+}\right] 1\right)$ [13]. These observations suggest that MDSC may be a major cause of $\mathrm{T}$ cell dysfunction and immunosuppression in COPD, and might therefore contribute to impairing tumor immune surveillance by allowing the proliferation of nascent transformed cells [48-52].

In a second study we hypothesized whether this pattern of expansion and activation of circulating MDSC associated to TCR $\zeta$ chain expression reduction could contribute to the increased risk of developing lung cancer in COPD patients [14]. We found higher percentages of MDSC as well as higher serum concentration of ARG 1 to a similar extent in lung cancer patients, COPD patients and patients with both entities, lung cancer and COPD (Figure 1). In these groups of patients we also found a reduction in the surface expression of TCR $\zeta$ in circulating lymphocytes compared with smokers without COPD and control non-smokers. Moreover, TCR $\zeta$ down-regulation was associated with $\mathrm{T}$ cell hyporesponsiveness in COPD and LC patients 


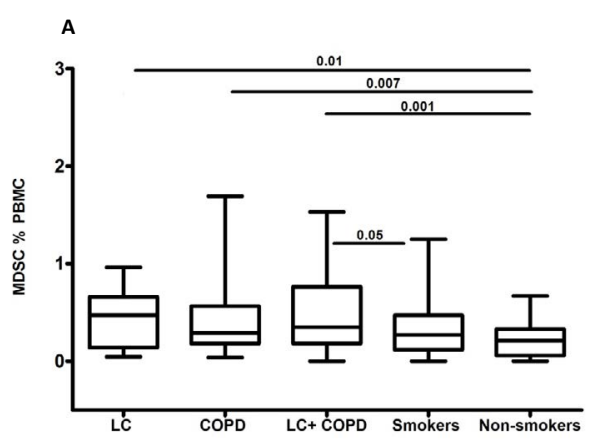

B

c
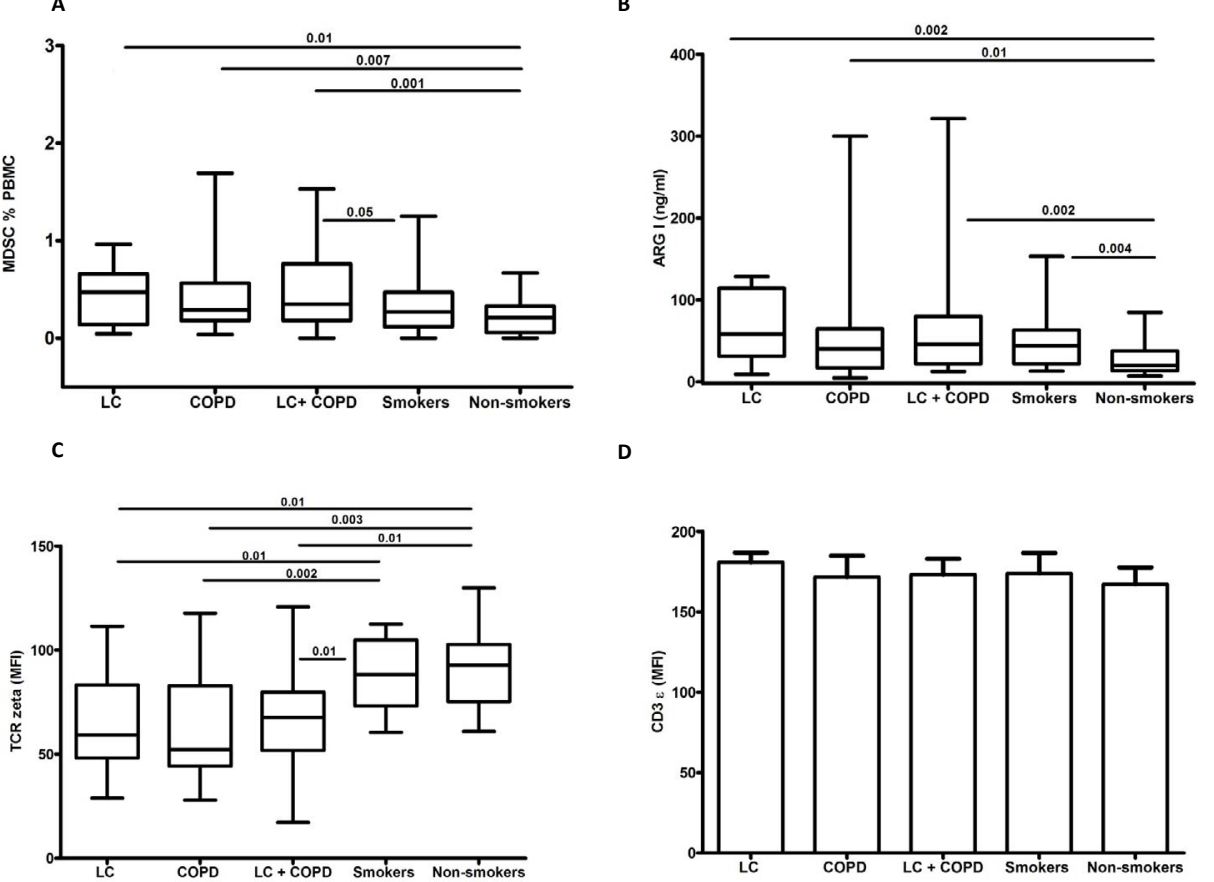

D

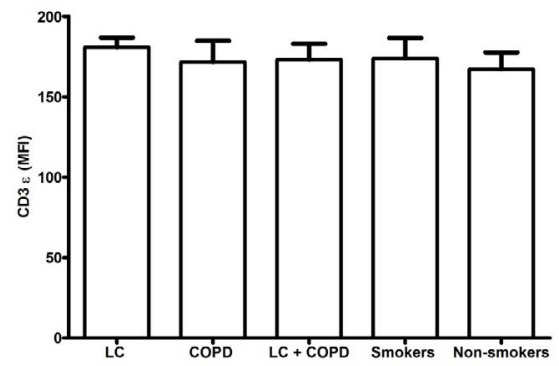

Figure 1. Circulating levels of MDSC (a), serum levels of arginase I (b), expression of TCR $\zeta$ chain (c) and $\operatorname{CD} 3 \varepsilon(\mathbf{d})$ in circulating T lymphocytes in the five groups studied. Figure reproduced from Scrimini et al. [14] with the permission of Springer. COPD, chronic obstructive pulmonary disease; LC, lung cancer; MFI, mean fluorescence intensity.

A

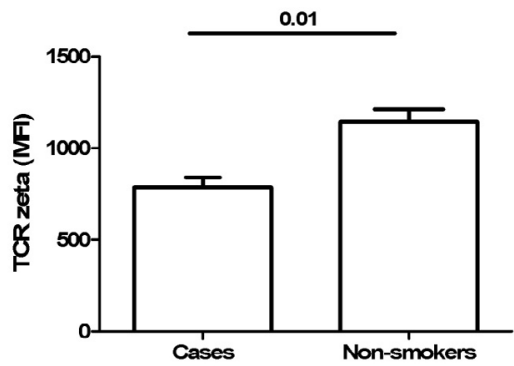

C

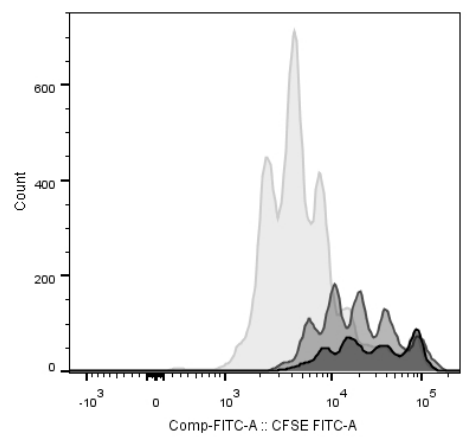

\begin{tabular}{|l|l|}
\hline$\square$ & Lung Canoer without COPD \\
\hline$\square$ & COPD \\
\hline$\square$ & Non-smoker \\
\hline
\end{tabular}
B
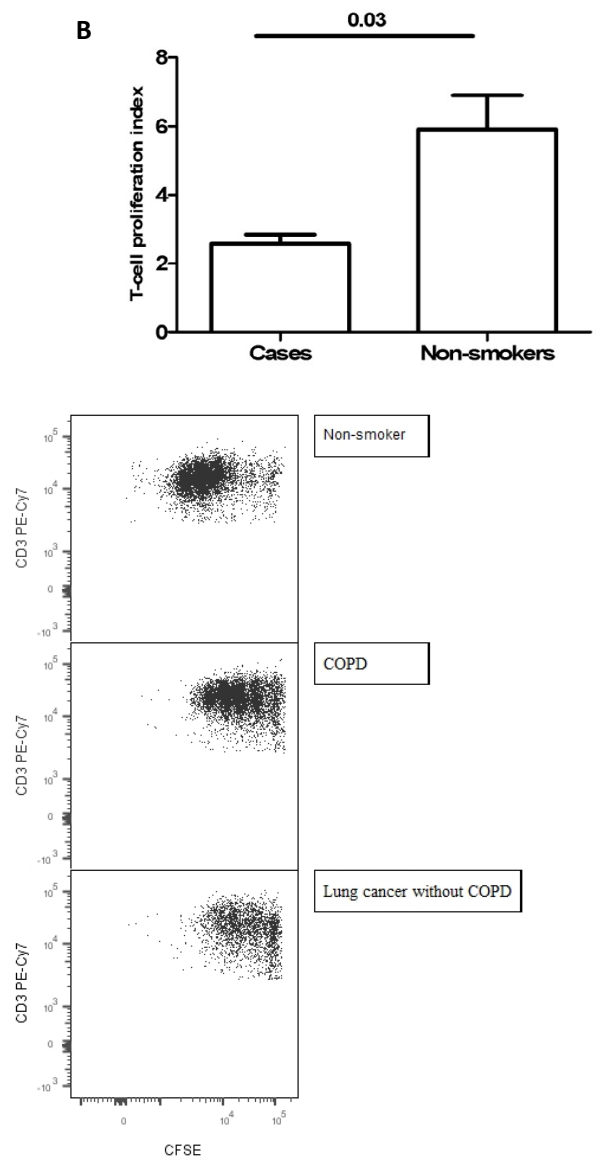

Figure 2. Expression of TCR $\zeta$ chain (a) and T cell proliferation assay using CFSE dilution protocol (b) in three cases (two COPD patients and one LC patient) and three healthy controls. Histograms and flow cytometry dot plots of T cell proliferation representative of LC, COPD and non-smoker control subjects (c). Figure reproduced from Scrimini et al. [14] with the permission of Springer. 


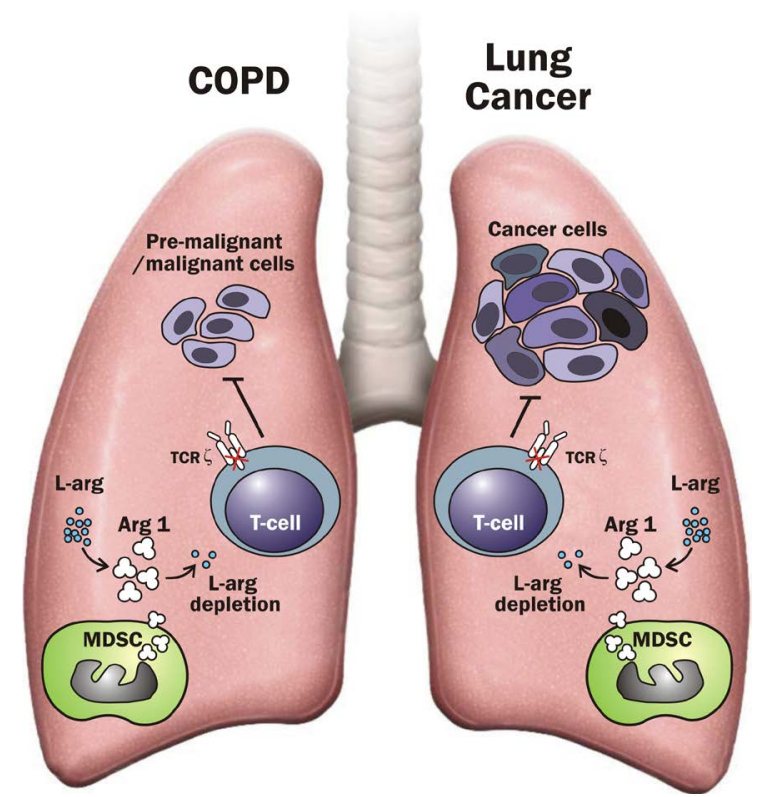

Figure 3. The role of myeloid-derived suppressor cells in COPD and lung cancer. Human myeloid-derived suppressor cells (MDSC) release Arginase 1 (ARG 1) and deprive $\mathrm{L}$-arginine (L-Arg). The shortage of L-arginine inhibits T-cell proliferation by decreasing T-cell receptor $\zeta$ expression (TCR $\zeta$ ) and, thereby, impairs T-cell function and alters antitumor immunity.

(Figure 2). These observations indicate that the immunossuppresive environment generated in hosts with lung cancer is also present in COPD patients and supports our working hypothesis that tumour immune surveillance might be altered in COPD patients (Figure 3) [14].

\section{Conclusion}

MDSC expansion associated with TCR $\zeta$ downregulaion and T cell dysfunction in COPD may alter tumour immune surveillance favouring the initial proliferation of tumour cells and contributing to the increased incidence of lung cancer in these patients.

\section{Funding}

Funding was received from the General Department of Research and Technological Development and Innovation of the Ministry of Innovation, Interior and Justice of the Autonomous Community of the Balearic Islands, and FEDER Funds. Competitive Groups (PRER22528-2011).

\section{References}

1. Vestbo J, Hurd SS, Agustí AG, Jones PW, Vogelmeier C, et al. (2013) Global strategy for the diagnosis, management, and prevention of chronic obstructive pulmonary disease: GOLD executive summary. Am J Respir Crit Care Med 187: 347-365. [Crossref]

2. Buist AS, McBurnie MA, Vollmer WM, Gillespie S, Burney P, et al. (2007) Internationa variation in the prevalence of COPD (the BOLD Study): a population-based prevalence study. Lancet 370: 741-750. [Crossref]

3. Lopez AD, Murray CC (1998) The global burden of disease, 1990-2020. Nat Med 4: 1241-1243. [Crossref]

4. Agustí A, Faner R (2012) Systemic inflammation and comorbidities in chronic obstructive pulmonary disease. Proc Am Thorac Soc 9: 43-46. [Crossref]

5. Barnes PJ, Celli BR (2009) Systemic manifestations and comorbidities of COPD. Eur Respir J 33: 1165-1185. [Crossref]

6. Sin DD, Anthonisen NR, Soriano JB, Agusti AG (2006) Mortality in COPD: Role of comorbidities. Eur Respir J 28: 1245-1257. [Crossref]
7. Grivennikov SI, Greten FR, Karin M (2010) Immunity, inflammation, and cancer. Cell 140: 883-899. [Crossref]

8. Swann JB, Smyth MJ (2007) Immune surveillance of tumors. J Clin Invest 117: 11371146. [Crossref]

9. Ostrand-Rosenberg S, Sinha P (2009) Myeloid-derived suppressor cells: linking inflammation and cancer. J Immunol 182: 4499-4506. [Crossref]

10. Rabinovich GA, Gabrilovich D, Sotomayor EM (2007) Immunosuppressive strategie that are mediated by tumor cells. Annu Rev Immunol 25: 267-296. [Crossref]

11. Serafini P (2013) Myeloid derived suppressor cells in physiological and pathological conditions: the good, the bad, and the ugly. Immunol Res 57: 172-184. [Crossref]

12. Scrimini S, Pons J, Agustí A, Soriano JB, Cosio BG, et al. (2013) Differential effects of smoking and COPD upon circulating myeloid derived suppressor cells. Respir Med 107: 1895-1903. [Crossref]

13. Kalathil SG, Lugade AA, Pradhan V, Miller A, Parameswaran GI, et al. (2014) T-regulatory cells and programmed death $1+\mathrm{T}$ cells contribute to effector T-cell dysfunction in patients with chronic obstructive pulmonary disease. Am J RespirCrit Care Med 190: 40-50. [Crossref]

14. Scrimini S, Pons J, Agustí A, Clemente A, Crespí Sallán M, et al. (2015) Expansion of myeloid derived suppressor cells in chronic obstructive pulmonary disease and lung cancer: potential link between inflammation and cancer. Cancer Immunol Immunother 64: 1261-1270. [Crossref]

15. WHO (2012) Globocan. Disponibleen. http://globocan.iarc.fr/Default.aspx. [Accessed 17.03.16].

16. Siegel RL, Miller KD, Jemal A (2015) Cancer statistics, 2015. CA Cancer J Clin 65 : 5-29. [Crossref]

17. Youlden DR, Cramb SM, Baade PD (2008) The International Epidemiology of Lung Cancer: geographical distribution and secular trends. J Thorac Oncol 3: 819-831. [Crossref]

18. Proctor RN (2012) The history of the discovery of the cigarette-lung cancer link: evidentiary traditions, corporate denial, global toll. Tob Control 21: 87-91. [Crossref]

19. Skillrud DM, Offord KP, Miller RD (1986) Higher risk of lung cancer in chronic obstructive pulmonary disease. A prospective, matched, controlled study. Ann Intern Med 105: 503-507. [Crossref]

20. Tockman MS, Anthonisen NR, Wright EC, Donithan MG (1987) Airways obstruction and the risk for lung cancer. Ann Intern Med 106: 512-518. [Crossref]

21. Congleton J, Muers MF (1995) The incidence of airflow obstruction in bronchial carcinoma, its relation to breathlessness, and response to bronchodilator therapy. Respir Med 89: 291-296. [Crossref]

22. Loganathan RS, Stover DE, Shi W, Venkatraman E (2006) Prevalence of COPD in women compared to men around the time of diagnosis of primary lung cancer. Chest 129: 1305-1312. [Crossref]

23. Young RP, Hopkins RJ, Christmas T, Black PN, Metcalf P, et al. (2009) COPD prevalence is increased in lung cancer, independent of age, sex and smoking history. Eur Respir J 34: 380-386. [Crossref]

24. Mannino DM, Aguayo SM, Petty TL, Redd SC (2003) Low lung function and inciden lung cancer in the United States: data From the First National Health and Nutrition Examination Survey follow-up. Arch Intern Med 163: 1475-1480. [Crossref]

25. Wasswa-Kintu S, Gan WQ, Man SF, Pare PD, Sin DD (2005) Relationship between reduced forced expiratory volume in one second and the risk of lung cancer: a systematic review and meta-analysis. Thorax 60: 570-575. [Crossref]

26. de Torres JP, Marín JM, Casanova C, Cote C, Carrizo S, et al. (2011) Lung cancer in patients with chronic obstructive pulmonary disease-- incidence and predicting factors. Am J Respir Crit Care Med 184: 913-919. [Crossref]

27. de Torres JP, Bastarrika G, Wisnivesky JP, Alcaide AB, Campo A, et al. (2007) Assessing the relationship between lung cancer risk and emphysema detected on lowdose CT of the chest. Chest 132: 1932-1938. [Crossref]

28. Wilson DO, Weissfeld JL, Balkan A, Schragin JG, Fuhrman CR, et al. (2008) Association of radiographic emphysema and airflow obstruction with lung cancer. $\mathrm{Am}$ J Respir Crit Care Med 178: 738-744. [Crossref]

29. Kanterman J, Sade-Feldman M, Baniyash M (2012) New insights into chronic inflammation-induced immunosuppression. Semin Cancer Biol 22: 307-318. [Crossref]

30. Baniyash M (2004) TCR zeta-chain downregulation: curtailing an excessive 
inflammatory immune response. Nat Rev Immunol 4: 675-687. [Crossref]

31. Gabrilovich DI, Nagaraj S (2009) Myeloid-derived suppressor cells as regulators of the immune system. Nat Rev Immunol 9: 162-174. [Crossref]

32. Youn JI, Gabrilovich DI (2010) The biology of myeloid-derived suppressor cells: the blessing and the curse of morphological and functional heterogeneity. Eur J Immunol 40: 2969-2975. [Crossref]

33. Bronte V, Zanovello P (2005) Regulation of immune responses by L-arginine metabolism. Nat Rev Immunol 5: 641-654. [Crossref]

34. Rodríguez PC, Ochoa AC (2008) Arginine regulation by myeloid derived suppressor cells and tolerance in cancer: mechanisms and therapeutic perspectives. Immunol Rev 222: 180-191. [Crossref]

35. Rodriguez PC, Hernandez CP, Quiceno D, Dubinett SM, Zabaleta J, et al. (2005) Arginase I in myeloid suppressor cells is induced by COX-2 in lung carcinoma. $J$ Exp Med 202: 931-939. [Crossref]

36. Rodriguez PC, Zea AH, Culotta KS, Zabaleta J, Ochoa JB, et al. (2002) Regulation of T cell receptor CD3zeta chain expression by L-arginine. J Biol Chem 277: 21123-21129. [Crossref]

37. Brownlie RJ, Zamoyska R (2013) T cell receptor signalling networks: branched, diversified and bounded. Nat Rev Immunol 13: 257-269. [Crossref]

38. Schmielau J, Finn OJ (2001) Activated granulocytes and granulocyte-derived hydrogen peroxide are the underlying mechanism of suppression of t-cell function in advanced cancer patients. Cancer Res 61: 4756-4760. [Crossref]

39. Bronstein-Sitton N, Cohen-Daniel L, Vaknin I, Ezernitchi AV, Leshem B, et al. (2003) Sustained exposure to bacterial antigen induces interferon-gamma-dependent $\mathrm{T}$ cell receptor zeta down-regulation and impaired T cell function. Nat Immunol 4: 957-964. [Crossref]

40. Ezernitchi AV, Vaknin I, Cohen-Daniel L, Levy O, Manaster E, et al. (2006) TCR zeta down-regulation under chronic inflammation is mediated by myeloid suppressor cells differentially distributed between various lymphatic organs. J Immunol 177: 47634772. [Crossref]

41. Liu CY, Wang YM, Wang CL, Feng PH, Ko HW, et al. (2010) Population alterations of L-arginase- and inducible nitric oxide synthase-expressed CD11b+/CD14 $/ \mathrm{CD} 15+/$ CD33+ myeloid-derived suppressor cells and CD8+ T lymphocytes in patients with advanced-stage non-small cell lung cancer. J Cancer Res Clin Oncol 136: 35-45. [Crossref]

42. Agustí AG, Noguera A, Sauleda J, Sala E, Pons J, et al. (2003) Systemic effects of chronic obstructive pulmonary disease. Eur Respir J 21: 347-360. [Crossref]

43. Thomsen M, Dahl M, Lange P, Vestbo J, Nordestgaard BG (2012) Inflammatory biomarkers and comorbidities in chronic obstructive pulmonary disease. Am J Respir Crit Care Med 186: 982-988. [Crossref]

44. Dahl M, Tybjaerg-Hansen A, Vestbo J, Lange P, Nordestgaard BG (2001) Elevated plasma ?brinogen associated with reduced pulmonary function and increased risk of chronic obstructive pulmonary disease. Am J Respir Crit Care Med 164: 1008-1011. [Crossref]

45. Gan WQ, Man SF, Senthilselvan A, Sin DD (2004) Association between chronic obstructive pulmonary disease and systemic inflammation: a systematic review and a meta-analysis. Thorax 59: 574-580. [Crossref]

46. Kolahian S, Öz HH, Zhou B, Griessinger CM, Rieber N, et al. (2016) The emerging role of myeloid-derived suppressor cells in lung diseases. Eur Respir J 47: 967-977. [Crossref]

47. Ortiz ML, Lu L, Ramachandran I, Gabrilovich DI (2014) Myeloid-derived suppressor cells in the development of lung cancer. Cancer Immunol Res 2: 50-58. [Crossref]

48. Schreiber RD, Old LJ, Smyth MJ (2011) Cancer immunoediting: integrating immunity's roles in cancer suppression and promotion. Science 331: 1565-1570. [Crossref]

49. Finn OJ (2008) Cancer immunology. N Engl J Med 358: 2704-2715. [Crossref]

50. Chen DS, Mellman I (2013) Oncology meets immunology: the cancer-immunity cycle. Immunity 39: 1-10. [Crossref]

51. Shankaran V, Ikeda H, Bruce AT, White JM, Swanson PE, et al. (2001) IFN gamma and lymphocytes prevent primary tumour development and shape tumour immunogenicity. Nature 410: 1107-1111. [Crossref]

52. Dunn GP, Old LJ, Schreiber RD (2004) The three Es of cancer immunoediting. Annu Rev Immunol 22: 329-360. [Crossref]

Copyright: (C2016 Scrimini S. This is an open-access article distributed under the terms of the Creative Commons Attribution License, which permits unrestricted use, distribution, and reproduction in any medium, provided the original author and source are credited. 